\title{
Evaluation of Vascular Endothelial Growth Factor, Hypoxia-inducible Factor 1-Alpha, and Bacterial Plaque Composition in Periodontal Health and Disease, with or without Bruxism: A Non-Randomized Clinical Study
}

\author{
Bruksizm Varlığında ve Yokluğunda, Periodontal Sağlık \\ ve Hastalıkta Vasküler Endotelyal Büyüme Faktörü, \\ Hipoksi ile İndüklenebilir Faktör 1-Alfa ve Bakteriyel \\ Plak Kompozisyonunun Değerlendirilmesi: Randomize \\ Olmayan Klinik Calıșma
}

\begin{abstract}
Aim: In this study, we aimed to evaluate the possible changes in hypoxia markers and bacterial components in patients with periodontitis and bruxism.

Methods: Four study groups were created: 20 healthy individuals without bruxism (Group 1), 20 periodontitis patients without bruxism (Group 2), 20 healthy individuals with bruxism (Group 3), and 20 periodontitis patients with bruxism (Group 4). Plaque index, gingival index, and clinical attachment levels were recorded and gingival crevicular fluid (GCF) and dental plaque samples were taken. The GCF vascular endothelial growth factor (VEGF) and hypoxia-inducible factor 1-alpha (HIF-la) levels were determined. Subgingival plaque samples were evaluated for 5 bacterial species (Aggregatibacter actinomycetemcomitans, Porphyromonas gingivalis, Tannerella forsythia, Treponema denticola, and Fusobacterium nucleatum).

Results: Compared to patients with periodontitis, plaque index, gingival index, and clinical attachmen levels were significantly lower in healthy individuals. The GCF and serum levels of VEGF and HIF-la were similar ( $p>0.05$ ). The A. actinomycetemcomitans, T. denticola, and F. nucleatum counts did not differ significantly between the study groups ( $p>0.05$ ). P. gingivalis counts were lowest in Group 1 and increased with both periodontitis and bruxism. T. forsythia counts were higher in Group 1 and Group 2 than in Group 3 and Group 4. The levels in Group 1 were lower than those in Group 2.

Conclusion: Individuals with and without bruxism were found to be similar in terms of hypoxia in periodontal health and disease. However, one of the major oral pathogens, P. gingivalis, is affected by the presence of bruxism, regardless of periodontitis.

Keywords: bruxism; hyperocclusion; hypoxia; periodontitis; subgingival microorganisms
\end{abstract}

Öz

Amaç: Bu çalıșmada periodontitis ve bruksizm hastalarında hipoksi belirteçlerindeki ve bakteriyel bileșenlerdeki olası değișiklikleri değerlendirmek amaçlanmıștır.

Yöntem: Dört çalıșma grubu olușturuldu: bruksizmi olmayan 20 sağlıkı birey (Grup 1), bruksizmi olmayan 20 periodontitis hastası (Grup 2), bruksizmi olan 20 sağlıklı birey (Grup 3) ve bruksizmi olan 20 periodontitis hastası (Grup 4). Plak indeksi, gingival indeks ve klinik ataçman seviyesi kaydedildi, dișeti oluğu sıvıs (DOS) ve dental plak örnekleri alındı. DOS'taki vasküler endotelyal büyüme faktörü (VEBF) ve hipoksi ile indüklenebilir faktör 1-alfa (HiF-la) seviyeleri belirlendi. Subgingival plak örnekleri 5 bakteri türü (Aggregatibacter actinomycetemcomitans, Porphyromonas gingivalis, Tannerella forsythia, Treponema denticola ve Fusobacterium nucleatum) için değerlendirildi.

Bulgular: Plak indeksi, gingival indeks ve klinik ataçman seviyesi periodontitis hastalarına kıyasla sağlıkl bireylerde anlamlı biçimde daha düșüktü. DOS ve serum VEBF ve HiF-la seviyeleri benzerdi $(p>0,05)$. A actinomycetemcomitans, T. denticola ve F. nucleatum sayıları çalıșma grupları arasında anlamlı farklıık göstermedi $(p>0,05)$. P. gingivalis sayıları Grup l'de en düșük olup hem periodontitis hem de bruksizm ile artmaktaydı. T. forsythia sayıları Grup 1 ve Grup 2'de Grup 3 ve Grup 4'e göre daha yüksekti. Grup l'dek seviyeler ise Grup 2'dekinden düșüktü.

Sonuc: Bruksizmi olan ve olmayan bireyler, periodontal sağlık ve hastalıkta hipoksi bakımından benzer bulunmuștur. Bununla birlikte, bașlıca oral patojenlerden biri olan P. gingivalis, periodontitisten bağımsız olarak bruksizm varlı̆̆ından etkilenmektedir.

Anahtar Sözcükler: bruksizm; hiperkoklüzyon; hipoksi; periodontitis; subgingival mikroorganizmalar
Nihat Akbulut', Ozkan Karatas ${ }^{2}$ Hatice Balci Yuce ${ }^{2}$, Sibel Akbulut ${ }^{3}$, Ahmet Altan', Mehmet Murat Taskan $^{2}$

Department of Oral and Maxillofacial Surgery, Faculty of Dentistry, Tokat Gaziosmanpașa University

2 Department of Periodontology, Faculty of Dentistry, Tokat Gaziosmanpaşa University

${ }^{3}$ Department of Orthodontics, Faculty of Dentistry, Tokat Gaziosmanpașa University
Received/Gelis : 12.05.2020 Accepted/Kabul: 11.10.2020

DOI: 10.21673/anadoluklin.736505

Corresponding author/Yazıșma yazarı Ahmet Altan

Ağız, Diș ve Cene Cerrahisi Anabilim Dalı, Diș Hekimliăi Fakültesi, Tokat Gaziosmanpașa Üniversitesi, Ali Șevki Erek Yerleșkesi, 60100 Tokat, Turkey

E-mail: dt.ahmetaltan@gmail.com

\section{ORCID}

Nihat Akbulut: 0000-0001-6950-8214 Ozkan Karatas: 0000-0001-9891-7172 Hatice Balci Yuce: 0000-0003-3574-9751 Sibel Akbulut: 0000-0003-3007-1179 Ahmet Altan: 0000-0003-2041-6364 M. Murat Taskan: 0000-0002-4830-0075 


\section{INTRODUCTION}

Periodontitis is an irreversible inflammatory disease of the periodontal tissues caused by the conversion of a symbiotic microbiota into a dysbiotic state. Systemic, genetic, or environmental factors can contribute to this change $(1,2)$. While the microbiota causes inflammation, the host is the responsible for periodontal destruction with increased proteinases and destruction of connective tissue fibers $(2,3)$. Bruxism is the major cause of occlusal trauma and may lead to hypoxic conditions in the subgingival area by causing stasis on blood vessels of the periodontal ligament (4). Occlusal trauma is one of the factors contributing to the progress of periodontal inflammation and can be defined as tissue destruction and/or injury leading to periodontal tissue changes as a result of excessive occlusal forces or hyperocclusion (5). Although there is a lack of evidence, previous studies reported that excessive occlusal forces facilitated the progression of inflammation into deep tissues, suggesting accelerated periodontal destruction around teeth with occlusal trauma and increased mobility $(6,7)$. Recent animal studies found that occlusal trauma led to increased osteoclastic activity and alveolar bone loss $(6,7)$. One possible mechanism suggested for the progression of periodontal destruction with excessive occlusal forces is that tooth mobility creates a subgingival environment conducive to overgrowth by periodontal pathogens (8). A possible association with occlusal trauma, microbiota and periodontal inflammation might be hypoxia due to periodontal pathogens such as Porphyromonas gingivalis and Fusobacterium nucleatum $(9,10)$. Furthermore, apart from periodontal infection, hypoxia can lead to inflammation with up-regulating pro-inflammatory mediators such as receptor activator of nuclear factor-kB ligand (RANKL) and interleukin (IL)-1 $\beta$ (11-13). However, the association of hypoxia, traumatic occlusion, and subgingival microbiota in periodontal health and disease was not evaluated in previous studies.

Evidence shows that traumatic occlusion alters the biochemical and physical structure of the surrounding tissues $(7,14,15)$. Compression that occurs in the periodontal ligament after excessive occlusal loads causes ischemia by blocking the blood flow and changing the vascular structure $(16,17)$. Ischemia leads to hypoxia and hypoxia induces the synthesis of pro-inflammatory cytokines such as interleukin (IL)- $1 \beta$ and collagen degrading enzymes such as matrix metalloproteinase- 8 in periodontal ligament cells and gingival fibroblasts $(18,19)$.

Hypoxia and inflammation are closely related since hypoxia increases inflammation and inflammation results in further hypoxic alterations in the periodontal tissue $(9,20)$. The presence of inflammation in gingival tissues was reported to increase hypoxia while the absence of inflammation in gingiva was associated with normal oxygen levels (9). In this relationship, the role of periodontal pathogens cannot be neglected. Low vascularization and oxygen tension after hypoxia favor anaerobic bacterial strains which mostly lead to microbial dysbiosis (19). On the other hand, the existence and abundance of anaerobic bacteria or bacterial products such as lipopolysaccharides (LPS) might also cause hypoxia (21). In this regard, studies reported that $P$. gingivalis and hypoxia induced RANKL, inflammatory cytokine, and apoptotic marker levels synergistically $(9,12)$. Hypoxia acts through hypoxia-inducible factors (HIF); HIF-1 $\alpha$ and HIF-1 $\alpha$ synthesis in gingival tissues is triggered by both lipopolysaccharides and hypoxia (22). Increase in hypoxia and periodontal HIF-1 1 levels could be an indicator of a hypoxic state and inflammation in the periodontium $(13,23,24)$. Recently, Vasconcelos et al. reported increased levels of HIF-1 $\alpha$ and VEGF in periodontal inflammation (24). Also, Afacan et al. demonstrated up-regulated HIF-1a, VEGF, and TNF- $\alpha$ levels which were suggested to be correlated with the severity and extent of periodontal inflammation (20).

The available studies regarding the effects of occlusal trauma on cytokine and mediator levels in the gingival tissue did not include an evaluation of subgingival microorganisms and hypoxia markers. Therefore, in this study we aimed to evaluate the possible changes in hypoxia markers and bacterial components of the gingival curriculum of teeth with excessive occlusal load. We also performed an evaluation of the GCF levels of VEGF and HIF- $1 \alpha$ and a semiquantitative determination of dysbiotic microbiota in subgingival dental plaque. 


\section{MATERIALS AND METHODS}

The study was conducted at the Department of Oral and Maxillofacial Surgery and Department of Periodontology of the the Tokat Gaziosmanpaşa University. A total of 80 participants were included and divided into 4 groups of 20 subjects each. Group 1 consisted of healthy individuals without bruxism; Group 2, periodontitis patients without bruxism; Group 3, healthy individuals with bruxism; and Group 4, periodontitis patients with bruxism. The sex distribution, mean age, and clinical measurements of each group are shown in Table 1.

Individuals who reported bruxism were examined at the Department of Oral and Maxillofacial Surgery. Individuals who were radiographically and clinically diagnosed with bruxism were enrolled in Group 3 and Group 4. The participants with no history and evidence of bruxism were enrolled in Group 1 and Group 2. The occlusal trauma diagnosis was made based on the following radiologic and clinical criteria: (i) widening of periodontal ligament (PDL); (ii) wear facets on the occlusal surfaces of the teeth; (iii) tooth mobility; (iv) tooth migration; (v) temporomandibular joint disorder; (vi) pain during chewing; and (vii) pain and stiffness in chewing muscles. All examinations were performed by an experienced surgeon (NA).

None of the participants was a smoker. All patients and healthy volunteers underwent detailed oral and radiographic examination. Full-mouth clinical periodontal measurements were recorded.

\section{Periodontal clinical parameters}

Periodontal health was examined, and the diagnosis was made based on the criteria defined by the 2017 International World Workshop for a Classification of Periodontal Diseases and Conditions (25). All periodontitis patients were stage III, grade B. Full-mouth clinical attachment level (CAL), plaque index (PI) (26), and gingival index (GI) (27) measurements at six sites per tooth (mesial, middle and distal aspects of both buccal and lingual/palatal surfaces) were performed. The CAL levels were measured using a Williams-type periodontal probe (Hu-Friedy Co., Chicago, IL, USA). The CAL was calculated as the distance in millimeters from the cementoenamel junction to the bottom of the periodontal pocket.

\section{Dental plaque sampling and determination of microorganisms}

In the periodontitis groups, the maxillary first/second molars with a CAL of 5-6 mm were chosen for dental plaque sampling. In the healthy groups, the maxillary first/second molars with a sulcus depth of $<3 \mathrm{~mm}$, no signs of inflammation, no gingival bleeding were chosen for dental plaque sampling. None of the teeth chosen had fillings, crowns, or any other sort of dental application. First, the relevant tooth was isolated from saliva with cotton rolls and dried with gauze. After supragingival plaque was removed, no.50 sterile paper points were placed inside the periodontal pocket (periodontitis groups) and gingival sulcus (healthy groups). Paper points were pushed until resistance was felt. The paper point was left in the pocket for 20 seconds and then removed. Five samples were obtained from each patient, combined in the same Eppendorf tube, and stored at $-20^{\circ} \mathrm{C}$. The subgingival microbial dental plaque samples were analyzed with a DNA isolation system (microIDent Plus ${ }^{\oplus}$, Hain Lifescience, Nehren, Germany). After their collection, all samples were sent to laboratory to be analyzed. The micro-IDent Plus test uses the PCR technique with subsequent reverse hybridization. The procedure includes the following steps, respectively: DNA/ RNA extraction, amplification of the extracted nucleic acid in a subsequent PCR reaction by taq polymerase enzyme and biotinylated primers, and the denaturation step to obtain single-stranded nucleic acid (amplicon), which is required for hybridization. In the hybridization stage the single-stranded amplicon specifically binds to membrane-bound probes. Following this process amplicons are visualized by enzymatic color reaction on the membrane.

The following bacterial strains were determined: Aggregatibacter actinomycetemcomitans (A. actinomycetemcomitans), Porphyromonas gingivalis (P. gingivalis), Tannerella forsythia (T. forsythia), Treponema denticola (T. denticola), and Fusobacterium nucleatum (F. nucleatum).

\section{Evaluation of the bacterial analysis}

For scoring, a datasheet containing semiquantitative bacterial counts was prepared for the micro-IDent kit. “-” was considered "0"; “(+)", score "1"; “+", score "2"; “++", score "3", and “+++", score “4”. 
Table 1. Participant demographics and clinical measurements

\begin{tabular}{|c|c|c|c|c|c|}
\hline & Age & Sex & Plaque index & Gingival index & Attachment loss \\
\hline Group 1 & $32.06 \pm 2.90$ & $\begin{array}{l}14 \mathrm{~F} \\
6 \mathrm{M}\end{array}$ & $0.50 \pm 0.50$ & $0.50 \pm 0.50$ & $2.20 \pm 0.75$ \\
\hline Group 2 & $36.90 \pm 4.67$ & $\begin{array}{l}14 \mathrm{~F} \\
6 \mathrm{M}\end{array}$ & $2.40 \pm 0.50^{\mathrm{a}}$ & $2.60 \pm 0.50^{\mathrm{a}}$ & $5.35 \pm 0.65^{\mathrm{a}}$ \\
\hline Group 3 & $34.89 \pm 7.51$ & $\begin{array}{l}15 \mathrm{~F} \\
5 \mathrm{M}\end{array}$ & $0.60 \pm 0.50^{\mathrm{b}}$ & $0.60 \pm 0.50^{\mathrm{b}}$ & $2.00 \pm 0.80^{\mathrm{b}}$ \\
\hline Group 4 & $36.76 \pm 4.40$ & $\begin{array}{l}13 \mathrm{~F} \\
7 \mathrm{M} \\
\end{array}$ & $2.50 \pm 0.50^{\mathrm{a}, \mathrm{c}}$ & $2.50 \pm 0.60^{\mathrm{a}, \mathrm{c}}$ & $5.50 \pm 0.70 \mathrm{a}, \mathrm{c}$ \\
\hline
\end{tabular}

${ }^{\mathrm{a}} \mathrm{p}<0.05$ vs. healthy individuals without bruxism

${ }^{\mathrm{b}} \mathrm{p}<0.05$ vs. periodontitis patients without bruxism

${ }^{c} \mathrm{p}<0.05$ vs. healthy individuals with bruxism

Table 2. The mean GCF and serum levels of VEGF and HIF-1a

\begin{tabular}{lllll}
\hline & VEGF $(G C F)$ & VEGF (serum) & HIF-1 $\alpha($ GCF $)$ & HIF-1 $($ serum) \\
\hline Group 1 & $61.02 \pm 121.05$ & $147.44 \pm 147.52$ & $0.06 \pm 0.12$ & $0.75 \pm 0.52$ \\
Group 2 & $45.64 \pm 23.51$ & $132.55 \pm 51.90$ & $0.04 \pm 0.01$ & $0.91 \pm 0.80$ \\
Group 3 & $70.51 \pm 173.44$ & $114.58 \pm 35.55$ & $0.03 \pm 0.00$ & $1.93 \pm 2.63$ \\
Group 4 & $122.75 \pm 247.64$ & $119.00 \pm 26.17$ & $0.04 \pm 0.01$ & $0.76 \pm 0.60$ \\
\hline
\end{tabular}

GCF: gingival crevicular fluid; HIF-1 $\alpha$ : hypoxia-inducible factor 1-alpha; VEGF: vascular endothelial growth factor

Table 3. The mean scores of semiquantitative analysis of subgingival bacteria

\begin{tabular}{lcccc}
\hline & A. actinomycetemcomitans & P. gingivalis & T. forsythia & T. denticola \\
\hline Group 1 & $1.25 \pm 1.45$ & $0.25 \pm 0.77$ & $1.81 \pm 1.22$ & $1.25 \pm 1.06$ \\
Group 2 & $1.75 \pm 1.86$ & $2.15 \pm 1.04^{\mathrm{a}}$ & $2.90 \pm 0.64^{\mathrm{a}}$ & $1.90 \pm 0.55$ \\
Group 3 & $0.68 \pm 1.10$ & $1.47 \pm 1.21^{\mathrm{a}, \mathrm{b}}$ & $2.01 \pm 0.82$ & $2.03 \pm 0.31$ \\
Group 4 & $0.82 \pm 1.01$ & $2.64 \pm 0.49^{\mathrm{a}, \mathrm{c}}$ & $3.02 \pm 0.65^{\mathrm{a}}$ & $1.70 \pm 1.04$ \\
\hline
\end{tabular}

${ }^{a} \mathrm{p}<0.05$ vs. healthy individuals without bruxism

${ }^{\mathrm{b}} \mathrm{p}<0.05$ vs. periodontitis patients without bruxism

${ }^{c} \mathrm{p}<0.05$ vs. healthy individuals with bruxism

\section{GCF sampling}

After an initial examination, teeth were chosen for dental plaque sampling and GCF sampling. GCF sampling was performed at the same teeth and sites as dental plaque sampling, one day after the plaque sampling. To prevent any contamination with saliva, the teeth were isolated with cotton rolls. The GCF samples were taken with paper strips (Periopaper, Pro Flow Inc., Amityville, NY, USA). Briefly, the strip was placed into the gingival sulcus or periodontal pocket until mild resistance was felt, and allowed to stand for $30 \mathrm{~s}$. Then, the strip was removed, placed into an Eppendorf tube and immediately frozen at $-80^{\circ} \mathrm{C}$ until the day of analysis. In the presence of contamination with saliva or blood, samples were repeated after 30 minutes.

\section{Serum sampling}

Venous blood was taken from the antecubital vein and allowed to stand for $30 \mathrm{~min}$ before centrifugation
(6,000 rpm for $10 \mathrm{~min})$. After centrifugation, the serum samples were placed into Eppendorf tubes and immediately frozen at $-80^{\circ} \mathrm{C}$ until the day of analysis.

\section{ELISA analysis}

The GCF and serum levels of VEGF (Invitrogen, Carlsbad, CA, USA) and HIF-1a (Elabscience Biotechnology Co., Beijing, China) were measured by ELISA. For the GCF samples, $150 \mu \mathrm{l}$ of phosphate buffer was added to each Eppendorf tube containing one paper strip and then mixed by vortex for $1 \mathrm{~min}$. After mixing, the strips were removed from the tubes. The materials were handled according to the manufacturers' instructions.

\section{Intra-examiner reproducibility}

All measurements were performed by one calibrated examiner, unaware of the study groups. The examiner underwent calibration training at the beginning 


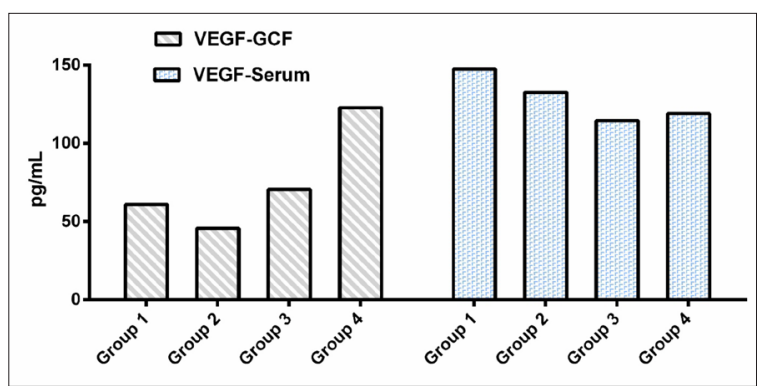

Figure 1. The gingival crevicular fluid (GCF) and serum levels of vascular endothelial growth factor (VEGF)

of the study and examined 10 patients not related to the study at two separate sessions, 48 -h apart. Calibration was accepted if the percentage agreement between measurements at baseline and after $48 \mathrm{~h}$ was greater than $90 \%$.

\section{Statistical analysis}

Power calculations were performed before the baseline survey. Eighty participants equally divided into the 4 study groups provided a statistical power of $>80 \%$. The data were expressed as mean and standard deviation, medians, scores, and percentages as appropriate. Analysis of normality was performed. For parametric tests, one-way ANOVA and Tukey, chi-square and Pearson correlation tests were used. For non-parametric tests, the Mann-Whitney U and Kruskal-Wallis tests were used. All statistical analysis was performed using the SPSS (v. 20.0) software. $\mathrm{p}<0.05$ was considered statistically significant.

\section{Study ethics}

The study protocol was approved by the Medical Ethics Committee of the Tokat Gaziosmanpaşa University (approval no. 16-KAEK-024). Written informed consent was obtained from all participants.

\section{RESULTS}

The sex distribution, mean age, and clinical measurements of each group are shown in Table 1. The mean VEGF and HIF- $1 \alpha$ levels are presented in Table 2. Semiquantitative bacterial counts are summarized in Table 3 .

There was no significant difference in sex distribution between the groups ( $p>0.05$ ). Healthy individuals were younger than periodontitis patients, but the mean ages were similar $(\mathrm{p}>0.05)$. The PI and GI values and CAL levels of healthy individuals were significantly lower than those of periodontitis patients $(\mathrm{p}<0.05)$ (Table 1). There was no significant difference in terms of PI and GI values and CAL levels either between Group 1 and Group 3 or between Group 2 and Group 4 ( $p>0.05$ ).

The VEGF levels were similar in the GCF and serum samples ( $p>0.05)$ (Figure 1). Likewise, there was no significant difference between the GCF and serum levels of HIF-1 $\alpha(\mathrm{p}>0.05)$ (Figure 2).

All groups exhibited similar counts of A. actinomycetemcomitans, T. denticola, and F. nucleatum ( $>>0.05$ ). The major changes were observed in the $P$. gingivalis evaluation. The $P$. gingivalis counts, lowest in Group 1 , were found to increase with both periodontitis and hyperfunction $(\mathrm{p}<0.05)$ (Table 3$).$ T. forsythia counts were higher in the groups without occlusal trauma than in the groups with occlusal trauma $(p<0.05)$. The levels in Group 1 were lower than those in Group 2 $(\mathrm{p}<0.05)$.

The Pearson correlation test showed a moderate negative correlation between the $P$. gingivalis counts and the GCF levels of HIF- $1 \alpha(r=0.40)$.

\section{DISCUSSION AND CONCLUSION}

The present study evaluated the hypoxic alterations in healthy and diseased periodontium with or without bruxism. The results revealed that the GCF levels of HIF-1 $\alpha$ and VEGF were similar in healthy and diseased periodontal tissues, and that these levels did not change with excessive occlusal loads. In addition, among the 5 bacterial species investigated, $P$. gingivalis was found to be correlated with the GCF levels of HIF-1a. Besides, T. forsythia levels were decreased in patients with bruxism.

In the presence of gingival inflammation, bruxism is considered to contribute to bone defects by leading to occlusal trauma (28), and occlusal trauma has been shown to cause a decrease in the amount of collagen and vascularization and an increase in leukocyte counts in the coronal regions of the periodontal ligament (29). Exacerbated inflammation via increased COX-2 and prostaglandine- 2 synthesis was also reported (30). In addition, Toll-like receptor-4 and interleukin- $1 \beta$ levels, related to tissue destruction, 


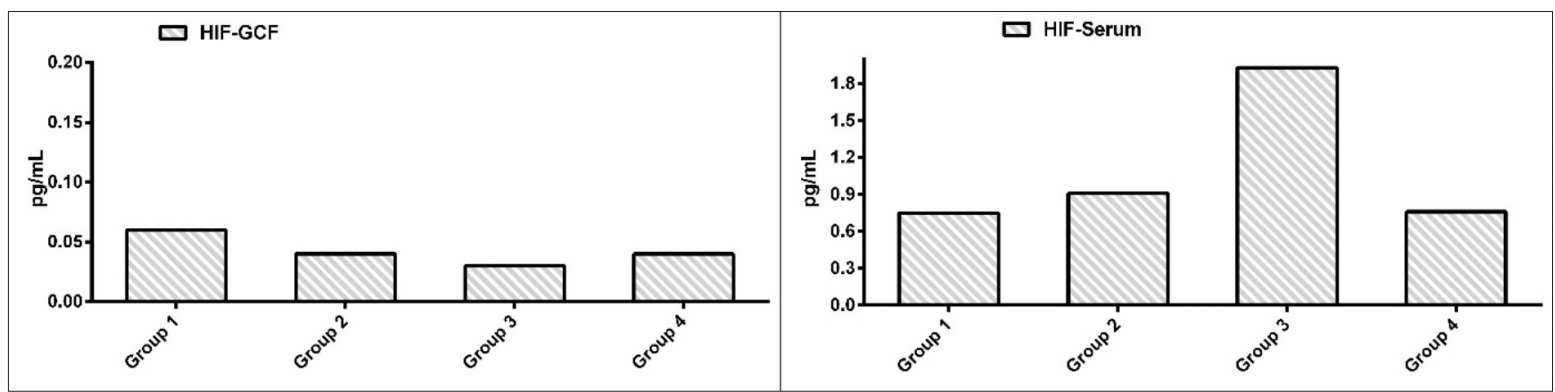

Figure 2. The GCF and serum levels of hypoxia-inducible factor 1-alpha (HIF-1 $\alpha$ )

were found to be elevated in rats with occlusal trauma (31). Tissue damage and inflammation in the periodontium lead to ischemia and hypoxia, and hypoxic periodontal ligament cells were reported to produce RANKL $(32,33)$. Furthermore, it is also suggested that increased bone resorption in occlusal trauma is caused by increased RANKL expression in the periodontal ligament cells $(34,35)$. Supporting these studies, Campos et al. reported that occlusal trauma increased osteoclastic activity and alveolar bone loss in rats (6). Also, Ispas et al. demonstrated increased tissue damage in rats with occlusal trauma (7). However, we found no significant difference between the gingival inflammation and clinical attachment levels of periodontitis patients with and without bruxism. Since this was a cross-sectional study, similarly matched patients were enrolled in the study groups. Therefore, it is natural that no significant difference was observed between the groups in terms of the periodontal parameters investigated. Longitudinal studies can demonstrate the effect of bruxism on periodontal tissues more clearly.

Both hypoxia and pro-inflammatory cytokines, also involved in periodontal inflammation, stimulate HIF-1 $\alpha$ synthesis (21). HIF-1 $\alpha$ mediates the short- and long-term hypoxic adaptations by upregulating VEGF expression, glycolysis, angiogenesis, and immune cell recruitment $(32,36)$. VEGF is expressed in a wide range of cells, including periodontal ligament fibroblast cells $(18,37)$. Recently, Gölz et al. demonstrated that VEGF synthesis in PDL fibroblasts was stimulated by both hypoxia and LPS of $P$. gingivalis along with the release of matrix metalloproteinase-1 (12). In addition to inflammation, mechanical stress can also trigger hypoxia and increase HIF-1 $\alpha$ and VEGF synthesis in the PDL fibroblast cells. Hypoxia, together with mechanical forces, can stimulate IL- $1 \beta$, IL- 6 , IL- 8 , TNF- $\alpha$ and
VEGF expressions in vitro (38). While in the absence of hypoxia HIF is rapidly degraded, in the presence of hypoxia HIF degradation is inhibited and hypoxiarelated alterations occur. However, it has recently been shown that HIF- $1 \alpha$ is detectable in healthy gingiva, even in the absence of any sign of visible inflammation $(9,11,20,39)$. Afacan et al. demonstrated increased HIF- $1 \alpha$, VEGF and TNF- $\alpha$ levels in the GCF and saliva of periodontitis patients, associated with the severity of the periodontal inflammation and attachment loss (20). In contrast, in a previous study of ours, we found no difference in HIF-1 $\alpha$ expressions in the gingival samples of patients with either periodontitis or diabetes and periodontitis (39). The present study aimed to determine the HIF-1 $\alpha$ and VEGF levels in patients with periodontitis and bruxism. Nonetheless, the GCF and serum levels of HIF and VEGF were similar in all healthy and periodontitis groups, indicating that bruxism, which leads to occlusal trauma, did not cause any difference in the cytokine levels. A possible reason is that either VEGF or HIF-1 $\alpha$ is not a specific marker for periodontal tissues. These can be synthesized by many other cells $(32,36)$, and their levels could be affected by other physiological processes in the human body.

LPS are known to stimulate HIF-1 $\alpha$ in monocytic cells by inducing the NF-KB pathway and cause a hypoxic milieu (21). Gölz et al. suggested that LPS of $P$. gingivalis and hypoxia together could contribute to periodontal destruction by increasing reactive oxygen species and oxidative stress (40). Though it did not specified bacterial strains, a study reported that hypoxia altered the bacterial diversity in rats (41). Also, Jian et al. demonstrated an up-regulation of pro-inflammatory cytokines such as TNF- $\alpha$, IL- $1 \beta$, and IL- 6 in the PDL cells subjected to hypoxia and $P$. gingivalis (42). In contrast, Takedachi reported that HIF-1a 
inhibited IL-6 and -8 expressions in the presence of hypoxia in $P$. gingivalis-induced inflammation (10). More recently, Cheng et al. demonstrated that LPS of $P$. gingivalis and hypoxia had a synergistic effect on periodontitis by increasing caspase-1 (9). Taken together, these results suggest that hypoxic conditions could modify the subgingival microbiota. We performed an analysis of 5 periodontal disease-related virulent bacterial strains in healthy individuals and periodontitis patients with and without bruxism, and found that $P$. gingivalis counts were affected by the existence of both periodontitis and bruxism. The increase in $P$. gingivalis levels was also demonstrated as a positive correlation between the GCF levels of HIF-1 $\alpha$ and the P. gingivalis levels. Orally healthy individuals with bruxism had higher $P$. gingivalis levels compared to those without bruxism. $P$. gingivalis is one of the most important bacteria in periodontal disease formation. Hypoxia, which is expected to occur due to bruxism, may also cause an increase in the amount of anaerobic bacteria, including $P$. gingivalis. However, we observed that T. forsythia levels were affected only by periodontitis, and that the study groups exhibited similar levels of $A$. actinomycetemcomitans, T. denticola, and F. nucleatum. This similarity could be expected as the inflammation levels were similar between the groups.

We used a commercial detection system (MicroIDent Plus ${ }^{\oplus}$, Hain Lifescience, Nehren, Germany) for our specific evaluation of bacterial species that could lead to dysbiosis. For the first time, Pfister and Eick used an early version of this test and reported that it was highly sensitive and specific (43). Then the test was used by several researchers and found to be effective in detecting certain bacterial strains in the microbiological diagnosis of periodontal diseases $(44,45)$. Haffajee et al. compared the efficacy of the Micro-IDent ${ }^{\circ}$ system with the checkerboard DNA-DNA hybridization technique and found that the two methods gave similar results for subgingival plaque samples obtained from periodontitis patients and healthy individuals (46). Commercial detection kits can be clinically useful, requiring less time and labor.

In conclusion, the present study evaluated the biochemical and microbiological alterations around teeth exposed to traumatic occlusion and teeth with normal occlusion. The results showed an increase in the $P$. gingivalis levels in patients with bruxism, and a positive correlation between $P$. gingivalis and HIF-1a levels. $P$. gingivalis levels are also expected to increase in anaerobic conditions with hypoxia. However, the GCF and serum samples showed no difference in terms of HIF- $1 \alpha$ and VEGF levels. There may be no difference in local and systemic markers because inflammation levels of the periodontitis patients with and without bruxism were moderate and equal. The role of occlusal trauma in periodontal inflammation was found to be unrelated to the microbiological alterations or hypoxia in periodontitis patients. Finally, these results should be interpreted considering the limitations of our study, which include the sensitivity of the commercial detection kit, lack of additional biochemical analysis, and small size of the study groups. Further studies involving larger groups and additional biochemical and microbiological analysis are recommended.

\section{Conflict-of-Interest and Financial Disclosure}

The authors declare that they have no conflict of interest to disclose. The project was supported with a grant from the Research Foundation of the Tokat Gaziosmanpaşa University (project no: 2016/19)

\section{REFERENCES}

1. Caton JG, Armitage G, Berglundh T, Chapple IL, Jepsen S, Kornman KS, et al. A new classification scheme for periodontal and peri-implant diseases and conditionsIntroduction and key changes from the 1999 classification. J Periodontol. 2018;89(Suppl. 1):S1-8.

2. Murakami S, Mealey BL, Mariotti A, Chapple IL. Dental plaque-induced gingival conditions. J Clin Periodontol. 2018;45(Suppl. 20):S17-27.

3. Tonetti MS, Greenwell H, Kornman KS. Staging and grading of periodontitis: framework and proposal of a new classification and case definition. J Periodontol. 2018;89(Suppl. 1):S159-72.

4. Deshpande RG, Mhatre S. TMJ disorders and occlusal splint therapy-a review. Int J Dent Clin. 2010;2(2):22-9.

5. Hallmon WW. Occlusal trauma: effect and impact on the periodontium. Ann Periodontol. 1999;4(1):102-8.

6. Campos M, Corrêa M, Junior F, Casati M, Sallum E, Sallum A. Cigarette smoke inhalation increases the alveolar bone loss caused by primary occlusal trauma in a rat model. J Periodontal Res. 2014;49(2):179-85. 
7. Ispas A, Mihu C, Crăciun A, Constantiniuc M. Morpho-histological assessment of the periodontal support structures under the action of excessive occlusal forces and under the influence of nicotine. Rom J Morphol Embryol. 2018;59(1):211.

8. Grant DA, Grant DA, Flynn MJ, Slots J. Periodontal microbiota of mobile and non-mobile teeth. J Periodontol. 1995;66(5):386-90.

9. Cheng R, Liu W, Zhang R, Feng Y, Bhowmick NA, Hu T. Porphyromonas gingivalis-derived lipopolysaccharide combines hypoxia to induce Caspase- 1 activation in periodontitis. Front Cell Infect Microbiol. 2017;7:474.

10. Takedachi M, Iyama M, Sawada K, Mori K, Yamamoto S, Morimoto $\mathrm{C}$, et al. Hypoxia-inducible factor- $1 \alpha$ inhibits interleukin- 6 and- 8 production in gingival epithelial cells during hypoxia. J Periodontal Res. 2017;52(1):127-34.

11. Ebersole JL, Novak MJ, Orraca L, Martinez-Gonzalez J, Kirakodu S, Chen KC, et al. Hypoxia-inducible transcription factors, HIF1A and HIF2A, increase in aging mucosal tissues. Immunology. 2018;154(3):452-64.

12. Gölz L, Memmert S, Rath-Deschner B, Jäger A, Appel T, Baumgarten G, et al. Hypoxia and P. gingivalis synergistically induce HIF-1 and NF- $\kappa$ B activation in PDL cells and periodontal diseases. Mediators Inflamm. 2015;2015:438085.

13. Mendes RT, Nguyen D, Stephens D, Pamuk F, Fernandes D, Hasturk H, et al. Hypoxia-induced endothelial cell responses-possible roles during periodontal disease. Clin Exp Dent Res. 2018;4(6):241-8.

14. Weng Y, Liu Y, Du H, Li L, Jing B, Zhang Q, et al. Glycosylation of DMP1 is essential for chondrogenesis of condylar cartilage. J Dent Res. 2017;96(13):1535-45.

15. Tsuzuki T, Kajiya H, Kazuko T, Tsutsumi T, Nemoto T, Okabe K, et al. Hyperocclusion stimulates the expression of collagen type XII in periodontal ligament. Arch Oral Biol. 2016;66:86-91.

16. Kvinnsland S, Kvinnsland I, Kristiansen AB. Effect of experimental traumatic occlusion on blood flow in the temporomandibular joint of the rat. Acta Odontol Scand. 1993;51(5):293-8.

17. Kvinnsland S, Kristiansen AB, Kvinnsland I, Heyeraas KJ. Effect of experimental traumatic occlusion on periodontal and pulpal blood flow. Acta Odontol Scand. 1992;50(4):211-9.

18. Motohira H, Hayashi J, Tatsumi J, Tajima M, Sakagami $\mathrm{H}$, Shin K. Hypoxia and reoxygenation augment boneresorbing factor production from human periodontal ligament cells. J Periodontol. 2007;78(9):1803-9.

19. Song ZC, Zhou W, Shu R, Ni J. Hypoxia induces apop- tosis and autophagic cell death in human periodontal ligament cells through HIF-1a pathway. Cell Prolif. 2012;45(3):239-48

20. Afacan B, Öztürk VÖ, Paşalı Ç, Bozkurt E, Köse T, Emingil G. Gingival crevicular fluid and salivary HIF-1 $\alpha$, VEGF, and TNF- $\alpha$ levels in periodontal health and disease. J Periodontol. 2019;90(7):788-97.

21. Frede S, Freitag P, Otto T, Heilmaier C, Fandrey J. The proinflammatory cytokine interleukin $1 \beta$ and hypoxia cooperatively induce the expression of adrenomedullin in ovarian carcinoma cells through hypoxia inducible factor 1 activation. Cancer Res. 2005;65(11):4690-7.

22. Li JP, Li FY, Xu A, Cheng B, Tsao SW, Fung ML, et al. Lipopolysaccharide and hypoxia-induced HIF-1 activation in human gingival fibroblasts. J Periodontol. 2012;83(6):816-24

23. Toker H, Balci Yuce H, Lektemur Alpan A, Gevrek F, Elmastas M. Morphometric and histopathological evaluation of the effect of grape seed proanthocyanidin on alveolar bone loss in experimental diabetes and periodontitis. J Periodontal Res. 2018;53(3):478-86.

24. Vasconcelos RC, Costa ALL, Freitas RA, Bezerra BA, Santos BR, Pinto LP, et al. Immunoexpression of HIF-1a and VEGF in periodontal disease and healthy gingival tissues. Braz Dent J. 2016;27(2):117-22.

25. Tonetti MS, Greenwell H, Kornman KS. Staging and grading of periodontitis: framework and proposal of a new classification and case definition. J Periodontol. 2018;89(Suppl. 1):S159-72.

26. Silness J, Loe H. Periodontal disease in pregnancy II. Correlation between oral hygiene and periodontal condition. Acta Odontol Scand. 1964;22:121-35.

27. Loe H, Silness J. Periodontal disease in pregnancy I. Prevalence and severity. Acta Odontol Scand. 1963;21:533-51.

28. Hallmon WW. Occlusal trauma-periodontal concerns. Tex Dent J. 2001;118(10):956-60.

29. Biancu S, Ericsson I, Lindhe J. Periodontal ligament tissue reactions to trauma and gingival inflammation. An experimental study in the beagle dog. J Clin Periodontol. 1995;22(10):772-9.

30. Shimizu N, Ozawa Y, Yamaguchi M, Goseki T, Ohzeki $\mathrm{K}$, Abiko Y. Induction of COX-2 expression by mechanical tension force in human periodontal ligament cells. J Periodontol. 1998;69(6):670-7.

31. Kong J, Yang Y, Sun S, Xie J, Lin X, Ji P. Effect of tolllike receptor 4 on synovial injury of temporomandibular joint in rats caused by occlusal interference. Mediators of Inflamm. 2016;2016:7694921. 
32. Huang LE, Bunn HF. Hypoxia-inducible factor and its biomedical relevance. J Biol Chem. 2003;278(22):19575-8.

33. Yu XJ, Xiao CJ, Du YM, Liu S, Du Y, Li S. Effect of hypoxia on the expression of RANKL/OPG in human periodontal ligament cells in vitro. Int J Clin Exp Pathol. 2015;8(10):12929-35.

34. Kim MS, Magno CL, Day CJ, Morrison NA. Induction of chemokines and chemokine receptors CCR2b and CCR4 in authentic human osteoclasts differentiated with RANKL and osteoclast like cells differentiated by MCP-1 and RANTES. J Cell Biochem. 2006;97(3):512-8.

35. Kaku M, Uoshima K, Yamashita Y, Miura H. Investigation of periodontal ligament reaction upon excessive occlusal load-osteopontin induction among periodontal ligament cells. J Periodontal Res. 2005;40(1):59-66.

36. Höpfl G, Ogunshola O, Gassmann M. HIFs and tumors-causes and consequences. Am J Physiol. 2004;286(4):R608-23.

37. Amemiya H, Matsuzaka K, Kokubu E, Ohta S, Inoue T. Cellular responses of rat periodontal ligament cells under hypoxia and re-oxygenation conditions in vitro. J Periodontal Res. 2008;43(3):322-7.

38. Chae HS, Park HJ, Hwang HR, Kwon A, Lim WH, Yi $\mathrm{WJ}$, et al. The effect of antioxidants on the production of pro-inflammatory cytokines and orthodontic tooth movement. Mol Cells. 2011;32(2):189-96.

39. Balci Yuce H, Karatas Ö, Tulu F, Altan A, Gevrek F. Effect of diabetes on collagen metabolism and hypoxia in human gingival tissue: a stereological, histopathological, and immunohistochemical study. Biotech Histochem. 2019;94(1):65-73.
40. Gölz L, Memmert S, Rath-Deschner B, Jäger A, Appel $\mathrm{T}$, Baumgarten $\mathrm{G}$, et al. LPS from P. gingivalis and hypoxia increases oxidative stress in periodontal ligament fibroblasts and contributes to periodontitis. Mediators Inflamm. 2014;2014:986264.

41. Xiao X, Li Y, Zhang G, Gao Y, Kong Y, Liu M, et al. Detection of bacterial diversity in rat's periodontitis model under imitational altitude hypoxia environment. Arch Oral Biol. 2012;57(1):23-9.

42. Jian C, Li C, Ren Y, He Y, Li Y, Feng X, et al. Hypoxia augments lipopolysaccharide-induced cytokine expression in periodontal ligament cells. Inflammation. 2014;37(5):1413-23.

43. Eick S, Pfister W. Comparison of microbial cultivation and a commercial PCR based method for detection of periodontopathogenic species in subgingival plaque samples. J Clin Periodontol. 2002;29(7):638-44.

44. Santigli E, Leitner E, Wimmer G, Kessler HH, Feierl G, Grube M, et al. Accuracy of commercial kits and published primer pairs for the detection of periodontopathogens. Clin Oral Investig. 2016;20(9):2515-28.

45. Petelin M, Perkič K, Seme K, Gašpirc B. Effect of repeated adjunctive antimicrobial photodynamic therapy on subgingival periodontal pathogens in the treatment of chronic periodontitis. Lasers Med Sci. 2015;30(6):164756.

46. Haffajee AD, Yaskell T, Torresyap G, Teles R, Socransky SS. Comparison between polymerase chain reactionbased and checkerboard DNA hybridization techniques for microbial assessment of subgingival plaque samples. J Clin Periodontol. 2009;36(8):642-9. 